\title{
1. The interaction between Europe's legal systems: an introduction to the investigation
}

\section{GOALS OF THE RESEARCH}

This book examines the broad issue of the rapprochement between the EU and ECHR legal systems. While there is a massive amount of literature in terms of monographs, collected volumes and national reports analyzing either the issue of the national application of EC/EU law or that of ECHR norms, a specific comparative analysis that takes into account the national judicial treatment of both laws is still lacking. This volume aims to answer the following research question: Are the EU and ECHR legal systems converging?

By 'convergence' we mean the possibility of encountering those structural principles that have traditionally contributed to the sui generis nature of EU law - namely direct effect and primacy - when dealing with the ECHR. This means that we are not going to compare the levels of protection of fundamental rights in these contexts but rather the impact that these two European legal systems have on national legal structures.

In order to answer this research question we are going to compare both the national judicial treatments of these two European legal systems and the interpretative approaches employed by the Strasbourg and Luxembourg Courts in cases that are sensitive for the national constitutional structures. This means that while the first part of this volume is going to focus on how national judges 'apply' EU law and the ECHR, the second part is going to be devoted, instead, to the European Courts, with an analysis of their origins and then of their recent attitudes. The research question of the first part is 'Are national judges treating the ECHR provisions the same way (or, at least, in a less different way than) they treat EU law?' The second part will investigate whether the Luxembourg and Strasbourg Courts have started adopting similar approaches when dealing with some sensitive areas touching the national constitutional structures. Obviously these two dynamics are strongly related and both European Courts have undergone deep transformations 
in recent years, especially after the enlargements of the EU and the Council of Europe.

This book originates from a very well known issue: according to many scholars, a clear distinction exists between ECHR and EU law, and this was recently pointed out by Lord Hoffmann in his Judicial Studies Board Annual Lecture (2009). ${ }^{1}$ Despite such important scholarship, after a detailed analysis of the national and European case law, this conclusion is questioned. On the contrary, at a first glance, at least in our view, it is possible to argue that, in a way, we are already dealing with partial convergence in the application of EU law and the provisions of the ECHR.

Convergence, like comparison, should be understood as a process: this means that the two legal orders under consideration might still present differences without this resulting in the impossibility of noticing some analogies. Moreover, even comparison refers to a process; comparing two 'things' does not mean to conclude that they are identical at the end of the process of comparison or that they were identical at the beginning of the process. Comparing does not exclude the possibility of finding differences.

The research question formulated at the beginning of this chapter does not seek to anticipate our conclusion: our research originates from the analysis of some factors present both at the national and supranational/ international level. In judgments like Omega Spielhallen, Schmidberger and, most recently, Sayn Wittgenstein the ECJ seemed to leave 'a margin of appreciation for Member States to maintain national constitutional specificities instead of imposing uniform solutions'. ${ }^{2}$ On the other hand,

1 'The fact that the 10 original Member States of the Council of Europe subscribed to a statement of human rights in the same terms did not mean that they had agreed to uniformity of the application of those abstract rights in each of their countries, still less in the 47 states which now belong. The situation is quite different from that of the European Economic Community, in which the Member States agreed that it was in their economic interest to have uniform laws on particular matters which were specified as being within European competence. On such matters, the European institutions, including the Court of Justice in Luxembourg, were given a mandate to unify the laws of Europe. The Strasbourg court, on the other hand, has no mandate to unify the laws of Europe on the many subjects which may arguably touch upon human rights ... The proposition that the Convention is a "living instrument" is the banner under which the Strasbourg court has assumed power to legislate what they consider to be required by "European public order", Lord Hoffmann, 'The Universality of Human Rights', Judicial Studies Board Annual Lecture, 19 March 2009.

2 C. Timmermans, 'Relationships between the Strasbourg Court and the ECJ', Intervention Round Table CCBE Luxembourg, 20 May 2011, http:// www.ccbe.org/fileadmin/user_upload/document/Roundtable_2011_Luxembourg/ Timmermans.pdf. 
if scholars had already noticed a certain convergence in countries like the Netherlands - where 'there is no fundamental divide between the application of public international law and EC law' ${ }^{3}$ - more recently even in contexts like Italy, for instance, national judges have started setting aside national law that conflicts with the ECHR in the absence of a norm comparable to those present in the Netherlands or in France.

The occasion for reflecting on this issue is given by the impact of the respective 'enlargements' of the two international organizations (the EU and the Council of Europe) to include Central and Eastern Europe, a situation which has induced the two European Courts to reconsider, partly at least, their mission. ${ }^{4}$ These factors represent the 'issue' that induced us to commence this research.

Finally, one might argue that the accession of the EU to the ECHR will give a definitive answer that will certainly favour convergence in the judicial treatment of these two European laws. We are not so sure about that. On the contrary, looking at the ECJ case law devoted to international treaties concluded by the EC, one can see how the ECJ has sometimes limited the perfect assimilation between 'EC law proper' and 'Community Agreements'. ${ }^{5}$ Moreover, recently, the ECJ has extended the WTO exception (lack of direct effect for WTO law norms) to the provisions of some other international law treaties. ${ }^{6}$ Cases like Mox Plant, ${ }^{7}$ then, reveal how the ECJ considers important the reasons connected to its interpretive monopoly and shows scant tolerance for interpretive competitors.

This is just a reminder of how the conclusions in this field are far from being obvious, even after the Reform Treaty, as always in the fascinating 'journey to an unknown destination'8 represented by European integration.

3 G. Betlem and A. Nollkaemper, 'Giving Effect to Public International Law and European Community Law before Domestic Courts. A Comparative Analysis of the Practice of Consistent Interpretation' (2003) Eur J Intl L 569.

4 On this, see: W. Sadurski, 'Partnering with Strasbourg: Constitutionalisation of the European Court of Human Rights, the Accession of Central and East European States to the Council of Europe, and the Idea of Pilot Judgments' (2009) Human Rights L Rev 397; O. Pollicino, L'allargamento ad est dell'Europa e rapporti tra Corti costituzionali e Corti europee. Verso una teoria generale dell'impatto interordinamentale del diritto sovranazionale? (Giuffrè 2010).

5 J. Bourgeois, 'The Effects of International Agreements in European Community Law: Are the Dice Cast?' (1984) 82 Michigan L Rev 1250.

6 See M. Bronckers, 'From "Direct Effect" to "Muted Dialogue": Recent Developments in the European Courts' Case Law on the WTO and Beyond' (2004) J Intl Economic Law 885.

7 C-459/03 European Commission v Ireland (2006) ECR I-4635.

8 J.H.H. Weiler, 'Journey to an Unknown Destination: A Retrospective and 


\section{TYPOLOGY OF RESEARCH AND THEORETICAL PREMISES: WHY JUDICIAL INTERACTIONS MATTER IN EUROPEAN CONSTITUTIONAL LAW}

This is case law based research; it does not seek to provide an answer to the question of the nature of EU law or the possibility of extending the notion of supranationalism ${ }^{9}$ to the ECHR. We are going to deal with a massive number of cases decided by national and European courts.

Why are we going to examine judicial interactions? What do they represent in the economy of this book? One of the starting assumptions of this work is that the interpretive action of judges is fundamental in order to understand the real impact of EU law and the ECHR on the domestic boundaries, as we are going to show in the following chapters. Judges create links between legal orders even in the absence of expressed norms of connections. Suffice it to think of those contexts originally characterized by the absence of a European clause, where judges adapted and reshaped the original wording of their national constitutions in order to provide a legal basis for explaining the authority of EC law.

The Italian case, for instance, is emblematic of this trend. When looking at the original Italian Constitution ${ }^{10}$ it is very hard to understand how the guardians of the Constitution have permitted the erosion of competences caused by EC/EU interference. Article11, in fact, 'agrees to limitations of sovereignty where they are necessary to allow for a legal system of peace and justice between nations, provided the principle of reciprocity is guaranteed'. ${ }^{11}$ This provision was conceived for Italy's participation in the UN or other limited-power organizations but not for the EU. The

Prospective of the European Court of Justice in the Arena of Political Integration' (1993) 31 J Common Market Studies 417.

9 J.H.H. Weiler, 'The Community System: the Dual Character of Supranationalism' (1981) Ybk Eur Law 267; P. Hay, Federalism and Supranational Organizations (University of Illinois Press 1966). For an overview of the different theories of supranationalism, R. Leal-Arcas, 'Theories of Supranationalism in the EU', 2006, http://law.bepress.com/cgi/viewcontent.cgi?Art.=8481\&context=expre sso\&sei-redir $=1 \#$ search $=\% 22$ supranationalism $\% 20$ weiler $\% 22$.

10 Article 11 of the Italian Constitution: 'Italy repudiates war as an instrument offending the liberty of the peoples and as a means for settling international disputes; it agrees to limitations of sovereignty where they are necessary to allow for a legal system of peace and justice between nations, provided the principle of reciprocity is guaranteed; it promotes and encourages international organizations furthering such ends'.

11 Italian Constitution, Article 11. 
latter imposes limitations of sovereignty for goals that go beyond the 'peace and justice between nations' mentioned in Article 11. The Italian Constitutional Court was forced to 'manipulate' the original meaning of Article 11 in order to allow such limitations. At the same time, when looking at Article 101 ('judges are only subject to the law'12), it is impossible to find the legal basis of the judge's power of non-application of the national rule contrasting with EU law.

The theoretical framework supporting the need for research like that we are proposing here can be linked to the existence of a multilevel constitutional legal order ${ }^{13}$ and of a constitution that is perceived as the outcome of the steady process of comparison and dialectic between interdependent levels of governance (Member States and the EU). Against this background, by European Constitutional law we mean that study committed to the analysis of a European Constitution thus conceived as a monstrum compositum, composed of constitutional principles developed at the European (Union) level and complemented by (common) national constitutional principles ${ }^{14}$ and by some other 'materials' like, for instance, the principles of the ECHR and the doctrines of the ECtHR.

Although the EU is not (yet) formally part of the ECHR, the Convention has always played a fundamental role in the progressive constitutionalization of the EU, working as a sort of external engine of such a process. Many fundamental judgments of the ECJ are very rich in references to the judgments of the ECtHR or to the provisions of the ECHR, and the Charter of Fundamental Rights of the EU was shaped, in many cases, with the provisions of the Convention in mind.

All this explains why, in the economy of this book, EU law, national law and the ECHR are conceived as the three sources of European constitutional pluralism. ${ }^{15}$ The interplay between levels (or poles/sites if we want

12 Italian Constitution, Article 101.

13 I. Pernice, 'Multilevel Constitutionalism and the Treaty of Amsterdam: European Constitution Making Revisited?' (1999) CML Rev 703; F. Mayer and I. Pernice, 'La costituzione integrata dell'Europa', in G. Zagrebelsky (ed.), Diritti e Costituzione nell' Unione Europea (Laterza) 43, 49; I. Pernice, 'Multilevel Constitutionalism in the European Union', (2002) Eur L Rev 511. On multilevel constitutionalism, see also L. Besselink, A Composite European Constitution/Een Samengestelde Europese Constitutie (Europa Law Publishing 2007).

14 See, among others: M. Claes, The National Courts' Mandate in the European Constitution (Hart 2006).

15 On constitutional pluralism, see N. MacCormick, 'Beyond the Sovereign State' (1993) 56 MLR 1. See also N. Walker, 'The Idea of Constitutional Pluralism' (2002) 65 MLR 317; M. Poiares Maduro, 'Contrapunctual Law: Europe's Constitutional Pluralism in Action' in N. Walker (ed.). Sovereignty in Transition, 
to avoid the word 'level'16) renders the idea of the non-simple distinction between the territorial actors' legislative domains. As a matter of fact, one of the most relevant difficulties in the multilevel legal system is represented by the existence of shared legal sources which make the attempt to define legal orders as self-contained regimes very difficult. This is coherent with the effort of providing an integrated and complex (i.e. interlaced ${ }^{17}$ ) reading of the levels, and represents one of the most fascinating challenges for constitutional law scholars.

At the same time, as a consequence of the lack of a precise distinction within the domain of legal production, it is sometimes impossible to resolve the antinomies between different legal levels on the grounds of the prevalence of a legal order (e.g. the national) over another (e.g. the supranational). Moreover, in this context, because of the inextricability of such an intertwined order, many legal conflicts present themselves as conflicts of norms (conceived as the outcome of the interpretation of legal provisions ${ }^{18}$ ) rather than conflicts of laws. ${ }^{19}$

One of the most evident differences between the EU and federal experiences is given by the absence of a supremacy clause. This has permitted the ECJ over the years to devise and reshape the content of the primacy principle, giving it an incredible flexibility. On the other hand, multilevel constitutionalism also suffers from the absence of an unambiguous primacy clause. Scholars have identified at least four different meanings of primacy/

(Hart, 2003) 501-37; M. Poiares Maduro, 'Interpreting European Law: Judicial Adjudication in a Context of Constitutional Pluralism' (2007) 2 Eur J Legal Studies, available at: http://ejls.eu/index.php?mode $=$ htmlarticle\&filename $=. /$ issues/2007-12/MaduroUK.htm. For a comparison between the different visions of constitutional pluralism, see M. Avbelj and J. Komarek (eds), 'Four Visions of Constitutional Pluralism', EUI Working Paper No. 28/2001, available at: http:// cadmus.iue.it/dspace/bitstream/1814/9372/1/LAW_2008_21.pdf. For a different concept of pluralism conceived as being in opposition to that of constitutionalism, see N. Krisch, 'Europe's Constitutional Monstrosity' (2005) 25 Oxford J Legal Studies 321. See also: S. Douglas-Scott, Constitutional Law, (Harlow Longman, 2002) 523-30.

16 Besselink, A Composite European Constitution.

17 G. Martinico, 'Complexity and Cultural Sources of Law in the EU Context: From the Multilevel Constitutionalism to the Constitutional Synallagma' (2007) German L J 205.

18 According to the distinction between statements (disposizioni) and norms (norme), see, V. Crisafulli, 'Disposizione (e norma)', in Enc. Dir., XIII (Giuffrè 1964) $195 \mathrm{ff}$.

19 J. Pauwelyn, Conflict of Norms in Public International Law. How WTO Law Relates to Other Rules of International Law (Cambridge University Press 2003) 6-8. 
supremacy in ECJ case law ${ }^{20}$ and the notion of primacy which came from I- 6 of the Constitutional Treaty seemed to be different from that used by the ECJ.

A consequence of the impossibility of tracing these principles back to the wording of a univocal primacy clause, ${ }^{21}$ for instance, has underscored the role of the judge. Our assumption is that this context exalts the case-bycase judicial approach to solving legal conflicts between rules. The impossibility of operating a distinction between legal orders implies the end of interpretative autonomy for these courts, showing the other side of the sovereignty crisis. Judicial interactions thus represent a privileged perspective for studying the relations between legal orders, especially when looking at the multilevel and pluralistic structure of the European constitutional legal system. ${ }^{22}$

\section{WHAT IS THE ROLE OF COMPARISON?}

From a methodological viewpoint, the intertwined nature of the European Constitution implies the massive use of comparative law concepts. First of all, in fact, it is not possible to understand the constitutional exchanges between levels without knowing the constitutional features of the horizontal state level. Secondly, the comparative method is one of the most important approaches carried out by the $\mathrm{ECJ}^{23}$ in the interpretation of EU law despite the few explicit comparative references contained in the judgments of the ECJ. Thirdly, the importance of the comparison is testified by the origin of the common constitutional traditions. Fourthly, the importance of foreign case law in the interpretation of constitutional law in general ${ }^{24}$

20 See, e.g, Claes, The National Courts' Mandate, 100-101.

21 Scholars have identified at least four different meanings of primacy/ supremacy in ECJ case law. Moreover, the notion of primacy enshrined in Article I- 6 of the Constitutional Treaty seems to be different from that used by the ECJ. See e.g. Claes, The National Courts' Mandate, 100-101. In order to find a solution to this ambiguity, some scholars have devised a 'law of laws'; see T. Eijsbouts and L. Besselink, 'Editorial: "The Law of Laws" - Overcoming Pluralism' (2008) Eur Constitutional L Rev 395.

22 G. Martinico, 'Judging in the Multilevel Legal Order: Exploring the Techniques of "Hidden Dialogue", (2010) 21 King's L J, 257.

23 A. Torres Pérez, Conflicts of Rights in the European Union (Oxford University Press 2009) 141-79.

24 S. Choudhry, 'Globalization in Search of Justification: Towards a Theory of Comparative Constitutional Interpretation' (1999) 74 Indiana L J 821; A. Slaughter, ‘A Typology of Transjudicial Communication' (1994) 29 U. Richmond 
provides us with another element: the emergence of constitutional flaws and exchanges in the contemporary global scenery.

The literature on the possible uses (and misuses) of comparative law in European (not only legal) studies is massive. Here we would like to recall that the idea of comparison as a third way in European studies was sponsored by the 'Integration through Law Scholarship' project, ${ }^{25}$ in order to analyze European integration in the light of the federal principle. That experiment did not neglect the peculiarity of the EU dimension because in their essays the participating scholars 'applied' a dynamic notion of federalism (Friedrich, ${ }^{26}$ Elazar $^{27}$ ). In doing so they understand federalism as a federalizing process, and federal principle, as a concept overcomes the classic distinction between federation, confederation and consortium. ${ }^{28}$

Obviously all these considerations touch the level, we would say, of the external comparison (i.e. the possibility to compare the EU as such to constitutional experiences of States that do not belong to the EU, like the US for instance) while we are going to insist on the 'internal' side of European constitutional law (and, as we said, the EU level is just a piece of this body of norms and principles). However, references to the 'external' comparison will not be missing when we deal with the complicated issue of the de facto rapprochement between the effects of EU law and that of the ECHR. Our

L Rev 99; A. Lollini, 'Legal Argumentation Based on Foreign Law. An Example from Case Law of the South African Constitutional Court', (2007) Utrecht L Rev 3: 60 .

25 M. Cappelletti, M. Seccombe and J.H.H. Weiler, Integration through Law: Europe and the American Federal Experience (1985).

26 C.J. Friedrich, Trends of Federalism in Theory and Practice (New York 1968).

27 D. Elazar, Idee e forme del federalismo (Mondadori 1995).

28 In 1994 Renaud Dehousse wrote about the lack of a comparative approach in European studies, stressing the benefits and the difficulties (the problem of the level of analysis) of comparison in this field. The refusal to make a comparison implies the 'absolutization' of the EU level and the consecutive denial of the European multilevel and pluralistic structure: 'In many respects, the situation of Community lawyers is similar to that of a scholar who would have confined himself to the study of his domestic legal system. Comparative research, with its corollary of relativism, may help him to challenge the assumptions rooted in his own legal system and counteract the "tendency of ultrasophisticated analysis and quasi-scholasticism which arises when generations of scholars continue to examine the same fundamental documents within a purely national context". In other words, one could argue that comparative research is indispensable if Community law is to move to a more advanced level of scholarship'. R. Dehousse, 'Comparing National and EC Law: The Problem of Level of Analysis' (1994) Am J Comparative Law 761, 764. 
attention to comparative data does not thus imply a lack of attention to the peculiar features of European integration. ${ }^{29}$

Starting from these considerations, our analysis proposes a 'multiple' comparison. In the first part of this work we will focus on the national level, analyzing the relevant constitutional provisions conceived or adopted for describing the effect of European laws within national boundaries. In the second part we are going to expand our perspective, taking into account the interactions between national and European levels, namely moving from the formal parameter (the constitutional provisions) to the law in action.

National (ordinary) judges have a fundamental role in the application of European laws and this implies the necessity to go beyond the positivist frame. This will be fundamental in order to investigate whether national actors use European laws. As we will see, despite the high degree of fragmentation and great variety in terms of the national constitutional clauses adopted by Member States to grant a basis to the ECHR and EU law, the case law of the different countries shows a certain homogeneity with regard to the effects and authority of EU law and the ECHR respectively.

Starting with EU law, a good example of this is the progressive diffusion of the 'counter-limits' or Solange doctrine in the jurisprudence of different constitutional courts in spite of the absence, in many cases, of provisions like 24 of the German Basic Law or Article 5, Chapter X, Paragraph 1 of the Swedish Instrument of Government. These, expressis verbis, condition the German and Swedish membership of the EU in respect of some fundamental values protected by the national constitution. By the 'counter-limits' $\left(\right.$ controlimiti $^{30}$ ) formula we mean those national fundamental principles which have been raised - like impenetrable barriers - against the penetration of EU law by the national constitutional courts. The 'counter-limits' are conceived as a form of 'contrepoid au pouvoir communautaire', 31 an ultimate barrier to the full application of EU law, an intangible nucleus of national constitutional sovereignty. ${ }^{32}$ The counter-limits doctrine ('dottrina

29 For a different viewpoint see I. Ward, A Critical Introduction to European Law (Butterworths 1996) $176 \mathrm{ff}$.

30 This formula was introduced in Italian scholarly debate by P. Barile, 'Ancora su diritto comunitario e diritto interno' in Studi per il XX anniversario dell' Assemblea costituente, VI (Florence 1969) 49.

31 About the notion of contrepoids au pouvoir, see: B. Manin, 'Frontières, freins et contrepoids - La séparation des pouvoirs dans le débat constitutionnel américain de 1787' (1994) Revue française de sciences politiques 257; T. Georgopoulos. 'The Checks and Balances Doctrine in Member States as a Rule of EC Law: The Cases of France and Germany' (2003) 9 Eur L J 530.

32 It is very interesting to notice that the notion of counter-limits implies a sort of constitutional and moral superiority of the national legal orders with 
dei controlimiti') was de facto conceived in case $183 / 73$ by the Italian Constitutional Court and (with some differences) in Solange $I$ by the German Bundesverfassungsgericht. ${ }^{33}$ Many constitutional courts accepted it in the following years the French Conseil Constitutionnel in $2004^{34}$ and the Tribunal Constitucional in Spain, ${ }^{35}$ but before them ${ }^{36}$ the English High Court admitted the primacy of EU law by preserving a hard core of principles. One of the most interesting cases is the Danish Carlsen, ${ }^{37}$ where the Supreme Court specified the possible dynamics of such a declaration. ${ }^{38}$ More recently the decisions of the Polish ${ }^{39}$ and German Constitutional Courts $^{40}$ (but see also the decisions of the Cypriot ${ }^{41}$ and Czech $^{42}$ judges)

regard to the supranational level. This form of constitutional superiority is usually justified by the existence of the democratic deficit which characterizes the EU. See, for example, Solange I (BVerfGE 37, S. $271 \mathrm{ff}$.): 'the Community still lacks a democratically legitimated parliament directly elected by general suffrage which possesses legislative powers and to which the Community organs empowered to legislate are fully responsible on a political level.'

33 BVerfGE 37, S. 271 ff., in http://www.bundesverfassungsgericht.de/en/ index.html.

34 But see also Conseil d'État, dec. Sarran, 30 October 1998; Cour de Cassation, dec. Fraisse, 2 June 2000; Conseil d'État, dec. SNIP, 3 December 2001. In addition see: Conseil Constitutionel 2004-496-497-498-499 DC 2004-505 DC.

35 Tribunal Constitucional, declaracion 1/2004. About this point, see V. Ferreres Comella, 'La Constitución española', 80-89, and A. Saiz Arnaiz, 'De primacia, supremazia y derechos fundamentales en la Europa integrada: la Declaración del Tribunal Constitucional de 13 diciembre de 2004 y el Tratado por el que establece una Constitución para Europa', both in A. Saiz Arnaiz and V. Ferreres Comella (eds), Constitución española y constitución europea (Centro deEstudios Políticos y Constitucionales, 2005), 51-75.

36 McWhirter and Gouriet $v$ Secretary of State for Foreign Affairs (2003) EWCA civ 384. On this point see A. Biondi, "Principio di supremazia e "Costituzione" inglese. I due casi "Martiri del sistema metrico" e "McWhirter and Gouriet", in www.forumcostituzionale.it/site/index3.php?option=com_content\&task=view\&i $\mathrm{d}=101 \&$ Itemid $=82$.

37 Højesteret, Carlsen v Rasmussen (1999) 3 CMLR 854.

38 According to the Carlsen doctrine, if there is a doubt about the consistency of the EC act with the Constitution, the constitutional court could raise the question by asking the ECJ to clarify the exact meaning of the norm. If the ECJ does not convince them of the compatibility, they could 'apply' the counter-limits theory. Such a vision demonstrates that the constitutional courts have the last word even though they have accepted the preliminary ruling.

39 Trybunat konstytucyjny, P 1/05, in http://www.trybunal.gov.p1/eng/index. htm.

40 BVerfG, $2 B v R$ 2236/04, in http://www.bundesverfassungsgericht.de/en/ index.html.

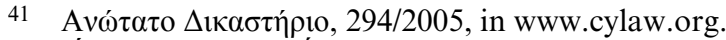

42 Ústavní Soud, Pl. ÚS 66/04, in http://test.concourt.cz/angl_verze/cases.html. 
have recalled the question of the ultimate barriers in the field of the European arrest warrant. This kind of comparison is therefore functional to the selection of those fundamental principles which had been opposed by the constitutional courts and which the ECJ later showed itself willing to accept in order to overcome the national courts' criticisms.

The second type of comparison we are going to develop is the vertical one (i.e. between Member States and the EU) in order to show the progressive communitarization of those constitutional principles that the constitutional courts have been opposing to the ECJ for many years.

The European Union is a complex legal order, since it stems from the interlacing between national and supranational legal systems. ${ }^{43}$ This implies the existence of shared legal sources (see the common constitutional traditions that are inferred from the national constitutional materials) and many principles of EU law find their 'roots' in the national legal traditions. Against this background the EU is indebted to national constitutional orders since they gave the EU new blood by favouring the circulation of principles and practices that have shaped and reshaped the substance of the Treaties. Such a situation is the outcome of a convergence between the starting positions held by the ECJ (monism) and the national constitutional courts (dualism) in the first years of European integration.

Progressively the ECJ has seemed to get the point by incorporating the concept of fundamental rights as a premise of the primacy of EU law, and new important provisions have been introduced in the Treaties, namely former Articles 6 and 7 of the EUT. Despite this convergence, tension between the ECJ and the constitutional courts has not been lacking because of the progressive expansion of the ECJ's activity in national fields. Moreover, the product of this convergence gave birth to new kinds of conflicts among interpreters, conflicts due to the existence of legal sources (the principles concerning the protection of fundamental rights) that are now shared by the ECJ and the national constitutional courts: such a scenario has produced a dynamics of interpretive competition.

The ECJ has progressively started acknowledging an important role to the national constitutional materials in its decisions. This 'partial' appropriation of the fundamental rights discourse by the ECJ emerges in a long series of judgments, and it is most evident in cases such as Omega ${ }^{44}$ and Dynamic Medien. ${ }^{45}$ As some authors have pointed out, from examining those cases one can perceive a certain concern over the

\footnotetext{
43 Martinico, 'Complexity and Cultural Sources of Law'.

44 C-36/02 Omega (2004) ECR I-9609.

45 C-244/06 Dynamic Medien (2008) ECR I-505.
} 
'octroyée methodology of construing common constitutional traditions' ${ }^{46}$ Nevertheless, this convergence is not total, as cases like Viking ${ }^{47}$ and Laval $^{48}$ demonstrate.

From the point of view of positive law, confirmation of such convergence can be seen in 4 of the EUT (post-Lisbon scenario) which codifies the respect paid by member states to the constitutional structure (whose core corresponds to the member states' fundamental principles, i.e. the counter-limits). As a result, the respect for the constitutional structure is governed by an EU provision and thus is under the ECJ's jurisdiction: in this sense we write of communitarization of the counter-limits. ${ }^{49}$ All this shows the presence of an overlapping zone between levels which is namely what we have called European constitutional law.

A similar situation already exists between the EU legal order and the ECHR system as, for instance, demonstrated by the progressive influence played by the Strasbourg Court over the Luxembourg Court ${ }^{50}$ and, on a more formalistic level, by the explanations to the Charter of Fundamental Rights of the EU which refer to the doctrine of the ECtHR and the provisions of the ECHR to a very great extent. ${ }^{51}$

This opens the door for the third type of comparison adopted in this volume: that between the ECHR and EU legal systems or, better, that between the approaches used by the respective courts.

46 M. Dani, 'Tracking Judicial Dialogue - The Scope for Preliminary Rulings from the Italian Constitutional Court', Jean Monnet Working Paper, 10/2008, available at http://centers.law.nyu.edu/jeanmonnet/papers/08/081001.html. See also the reactions to the Mangold case (C-144/04, Mangold (2005) ECR I-9981): Roman Herzog and Lüder Gerken, '(Comment) Stop the European Court of Justice', http://euobserver.com/9/26714. This piece is the translation of an article originally published in German: 'Stoppt den Europäischen Gerichtshof', Frankfurter Allgemeine Zeitung, 8 September 2008.

47 C-438/05 The International Transport Workers' Federation and The Finnish Seamen's Union (2007) ECR I-10779 and C-341/05 Laval un Partneri Ltd /Svenska Byggnadsarbetareförbundet (2007) ECR I-11767.

48 Laval.

49 A. Ruggeri, “"Tradizioni costituzionali comuni" e "controlimiti”, tra teoria delle fonti e teoria dell'interpretazione' (2003) 1, Dir. Pub. Comp. e Eur, 102-120.

50 See S. Douglas-Scott, 'A Tale of Two Courts: Luxembourg, Strasbourg and the Growing European Human Rights Acquis' (2006) CML Rev 629; See also K. Kuhnert, 'Bosphorus Double Standards in European Human Rights Protection?' (2006) 2 Utrecht L Rev, 177 and ECtHR, Bosphorus Hava v Ireland, judgment of 30 June 2005.

51 On this see: G. Martinico, 'Interpretation as Constitutional Disagreement. On Some (Political) Attempts to Hijack the European Integration Process', in R Toniatti (ed.) The Law Maker's Interpretation. How the Law Controls Interpretation (Wolf Legal Publisher, forthcoming). 
When looking at the recent history of integration it seems possible to detect an embryonic rapprochement between EU law and ECHR law. Indeed, the enlargements of the Council of Europe and of the European Union have caused two opposite reactions in the Strasbourg and Luxembourg Courts: the Strasbourg Court has accelerated, acting as a quasi-constitutional court, while the ECJ has sometimes drawn back by referring to a 'compromise' - a softened version of primacy. Such a double process makes the two supranational courts more similar with regard to their own idea of the impact of the respective case law on the domestic legal orders. ${ }^{52}$ At the same time, judgments like Lautsi $I{ }^{53}$ or Elchinov, ${ }^{54}$ Zambrano $^{55}$ and Cordero Alonso ${ }^{56}$ show how there is no clear trend in the approach of these two courts to the domestic constitutional structures. We are going to deal with these judicial trends in the second part of this volume.

\section{STRUCTURE OF THE WORK}

This book reflects the double side of our investigation: in the first part of the volume we will study the 'vertical' (hypothesized) convergence between EU law and the ECHR, focusing on national judges, while in the second our focus will be the progressive 'horizontal' (hypothesized) convergence between the Luxembourg and Strasbourg Courts. In both cases a fundamental role is played by the ECJ case law on fundamental rights, which has allowed the birth of a common axiological platform between the EU and the member states, and the EU and the ECHR.

52 For an overview on the impact of the ECHR on the domestic legal orders see: H. Keller and A. Stone Sweet (eds), A Europe of Rights: The Impact of the ECHR on National Legal Systems (Oxford University Press 2008); G. Martinico and O. Pollicino (eds), The National Judicial Treatment of the ECHR and EU Laws. A Comparative Constitutional Perspective (Europa Law Publishing 2010).

53 Case of Lautsi and others v Italy (Application no. 30814/06), http://www. echr.coe.int/echr/resources/hudoc/lautsi_and_others_v_italy.pdf.

54 C-173/09, Elchinov, www.curia.europa.eu. On Elchinov, see: M. Eliantonio and C. Backes, 'Taking Constitutionalization One Step Too Far? The Need for Revision of the Rheinmühlen Case Law in the Light of the AG Opinion and the ECJ's Ruling in Elchinov', Maastricht Faculty of Law Working Paper, 2010/9, http://papers.ssrn.com/sol3/papers.cfm?abstract_id=1722631.

55 C-34/09, Gerardo Ruiz Zambrano v Office national de l'emploi (ONEM), http://curia.europa.eu/jurisp/cgi-bin/form.pl?lang=EN\&Submit=rechercher\&num aff $=$ C $-34 / 09$.

56 C-81/05 Cordero Alonso (2006) ECR I-7569. 
Convergence does not obviously mean perfect coincidence but it describes a process of mutual rapprochement between legal entities characterized by different aims at the origins. Despite the judicial conflicts that sometimes exist between judicial actors, our impression is that we are dealing with a sort of cooperative climate between judges who prefer to guarantee the coherence between legal systems (in the name of the protection of those fundamental rights which represent the common axiological field in the multilevel context), especially through the development of informal ways of dialogue, which recall the international public law experience of judicial comity and judicial deference.

In this sense it is possible to compare judgments such as Bosphorus ${ }^{57}$ to the famous Solange I case. As we know, the Solange method ${ }^{58}$ implies the $^{-}$ recognition of a 'reserve jurisdiction' for domestic courts and the acknowledgment to EC law of a sort of limited primacy: such primacy is guaranteed as long as it does not affect the national constitutional fundamental principles (the 'counter-limits'). Looking at the relationship between the constitutional courts and the ECJ one could notice some common points shared between the Solange method and comity, Solange being a way to find a solution to the matter of jurisdictional competition induced by the fragmentation of law. 59

According to Lavranos - who tried to extend the definition of the 'as long as' method to other inter-jurisdictional relations beyond the EU6 the 'Solange method' is thus defined as a tool for determining the scope of the 'reserve jurisdiction' of one court in relation to the existing jurisdiction of another court. Applying this Solange method results in refraining from exercising an existing jurisdiction of one court in favour of an existing jurisdiction of another court. ${ }^{61}$

57 Bosphorus Hava v Ireland.

58 On the Solange method see Ni. Lavranos, 'Towards a Solange-Method between International Courts and Tribunals?' in Y. Shany and T. Broude, The Shifting Allocation of Authority in International Law: Considering Sovereignty, Supremacy and Subsidiarity (Hart 2008) 217.

59 N. Lavranos, 'From the analysis above it can be concluded that the Solangemethod can help to reduce the chance of conflicting or diverging rulings, and thus the potential for fragmentation of fundamental rights in Europe is contained. Similarly, a wider application of the Solange-method by all international courts and tribunals could equally reduce the risk of fragmentation of international law', Lavranos, 'Towards a Solange-Method', 232.

60 See N. Lavranos, 'Regulating Competing Jurisdictions among International Courts and Tribunals' (2008) Heidelberg J Intl L, 575.

61 Lavranos, 'Towards a Solange-Method', 219. 
In the Bosphorus ${ }^{62}$ case, the ECtHR refused to review an EC regulation implementing a UN Security Council resolution, although the content of such an EC act was restrictive of the property right. The conclusion reached by the Strasbourg Court was inspired by the conviction of the comparability between the system of safeguarding fundamental rights which is guaranteed at the EU level and that provided by the ECHR. In Bosphorus the ECtHR used the same formula ('as long as') adopted by the German Constitutional Court in Solange to introduce a sort of presumption of comparability preventing a clash between jurisdictions. ${ }^{63}$

In the above mentioned cases, courts, despite the prima facie impression of judicial clash, preferred to act as cooperative actors and in this sense we conclude for the possible birth of a cooperative constitutionalism, which is the outcome of a process of 'integration through rights'. ${ }^{64}$

Again, this confirms the importance of judicial interactions (maybe we could say judicial dialogue) in these dynamics and the existence of a circulation of models (interpretative techniques, approaches, styles) among judges.

62 Bosphorus Hava v Ireland.

63 'Paradoxically, the safeguard of core rights, far from being the reason for the application of the counter-limit doctrine, was used as a harmonizing platform, and both tribunals sacrificed their own particular conception to pledge allegiance to the Court of Justice, or to support it.' F. Fontanelli in G. Martinico and F. Fontanelli, 'The Hidden Dialogue: When Judicial Competitors Collaborate' (2008) 8.3 Global Jurist.

64 L. Scheeck, 'The Relationship between the European Courts and Integration through Human Rights' (2005) Zeitschrift für ausländisches öffentliches Recht und Völkerrecht 837. 